\title{
Collaboration, Collaborators, WAC and Conflict: Archaeology and Peacebuilding in Northern Ireland
}

\author{
Audrey Horning, College of William and Mary, Williamsburg, VA, USA; Queen's \\ University Belfast, Belfast, Northern Ireland, UK \\ E-mail: ajhorn@wm.edu; a.horning@qub.ac.uk
}

\begin{abstract}
Collaboration in contemporary archaeological parlance principally refers to active engagement with one or more selected groups of stakeholders and co-producers of knowledge. Yet to be a "collaborator" in conflict settings implies an allegiance, often deceitful, to one cause or another. When embedding archaeology in conflict transformation activities, being seen as a "collaborator", or partisan, can therefore actively work against the aims of peacebuilding. Drawing upon experience in conflict transformation within post-Troubles Northern Ireland, issues of ethics and positionality are considered, and an alternative terminology for embedding archaeology in peacebuilding activity is posited.
\end{abstract}

Résumé: La collaboration dans le jargon archéologique contemporain fait essentiellement référence à un engagement actif auprès d'un ou de plusieurs groupes désignés de parties prenantes et de co-créateurs de savoirs. Cependant, être un « collaborateur » dans une zone de conflit implique une allégeance, souvent trompeuse, envers une cause ou une autre. Lors de l'intégration de l'archéologie aux activités de transformation d'un conflit, être vu comme un " collaborateur » ou un partisan, est par conséquent susceptible de nuire activement aux objectifs des efforts de consolidation de la paix. S'inspirant d'une expérience en matière de transformation de conflit en Irlande du Nord après les troubles, des questions d'éthique et de positionnalité sont examinées et une terminologie alternative pour l'intégration de l'archéologie dans une activité de consolidation de la paix est proposée.

Resumen: La colaboración en el lenguaje arqueológico contemporáneo se refiere principalmente al compromiso activo con uno o más grupos seleccionados de partes interesadas y coproductores de conocimiento. Sin embargo, ser un "colaborador" en situaciones de conflicto implica una lealtad, a menudo engañosa, a una causa u otra. Al incorporar la 
arqueología en las actividades de transformación de conflictos, ser visto como "colaborador" o partidista, por lo tanto, puede tener el impacto de socavar los objetivos de la construcción de la paz. Basándose en la experiencia en la transformación de conflictos en Irlanda del Norte después de los problemas, se consideran cuestiones de ética y de posición, y se plantea una terminología alternativa para integrar la arqueología en la actividad de la consolidación de la paz.

\section{KEY WORDS}

Collaboration, Conflict, Northern Ireland, Peacebuilding

\section{Introduction: Troubling Terms}

Collaboration in contemporary archaeological parlance principally refers to active engagement with one or more selected groups of stakeholders and co-producers of knowledge. The vast majority of collaborative projects rest upon a model whereby archaeologists actively engage with marginalised groups and work towards adjusting the asymmetries of power and voice, often-consciously or not-in acts of atonement for the many sins of our discipline. In other words, it is usually easy to see with which group an archaeologist should side, particularly when it comes to addressing colonial legacies and the need to incorporate different forms of knowledge-making (see for example discussions in Atalay 2012; Colwell-Chanthaphonh and Ferguson 2008; Martindale and Nicholas 2014; Nicholas 2010; Silliman 2008). Archaeologists can be rightly proud of a growing social consciousness and of making positive contributions to the wellbeing of disenfranchised groups in the present, and to restoring the validity of overlooked stories from the past, as ably demonstrated by many of the contributions in this special issue. But positionality-choosing sides-in conflict and post-conflict settings is not always so straightforward, and nor should it be. Knowledge is always produced for a purpose. To be a "collaborator" in conflict settings implies an allegiance, often deceitful, to one cause or another, and by intent or by default, contributing to or prolonging conflict and violence. Language, in these settings, must be chosen very carefully.

In questioning the use of the term collaboration, my intention is not to introduce some unhelpful, esoteric semantic diatribe as some form of egotistical insertion of self into archaeological debate. I raise this concern and caution from a practice-based standpoint, working actively in an effort to 
embed archaeology in conflict transformation in Northern Ireland. Being seen as a "collaborator", or partisan, would actively work against these aims of peacebuilding in the Northern Irish context, a context with clear parallels with other post-conflict settings. The peculiarities of Northern Irish society, where neither community (Catholic/Nationalist/Republican and Protestant/Unionist/Loyalist) holds a demographic majority, demand a pragmatic approach that engages across the divide. Orienting heritage practice towards conflict transformation requires engagement with the widest possible range of individuals including perpetrators of violence as well as those who suffered violence (as discussed further below). This form of practice should not be confused with the neoliberal multivocality that has recently been the object of scorn by commentators such as González-Ruibal (2018, 2019) and La Salle and Hutchings (2018), nor as any tacit support for violence in the past, present, or future. In the context of post-Troubles Northern Ireland, pragmatism emerges as the most effective paradigm for a future-oriented, epistemologically honest, and ethically grounded archaeology (Horning 2019 for pragmatic orientations in archaeology; see also Mrozowski 2011; Preucel and Mrozowski 2010; and Preucel and Bauer 2001).

\section{Background: The Troubles}

The sectarian conflict in Northern Ireland, known as the Troubles, lasted for 30 years (1968-1998), and was marked by intermittent violence that killed over 3500 and injured more than 50,000 (Sutton 2001). First sparked by demands for Civil Rights by an expanding Catholic community, traditionally disenfranchised in what had been a majority Protestant land since the 1922 partition of Ireland into the independent Free State (now Republic of Ireland) and Northern Ireland (as part of the United Kingdom), the conflict devolved into sectarian violence. Key events of the Troubles are well-known: Bloody Sunday on 30 January 1972 when British Army officers opened fire on unarmed protesters in the Bogside neighbourhood of the city of Derry/Londonderry, killing 14 Catholic civilians; the Hunger Strikes by Republican (Catholic) prisoners in 1980-1981 protesting their treatment as criminals rather than as political prisoners; the 1987 killing of ten Protestant civilians at a Remembrance Day ceremony in Enniskillen by an Irish Republican Army (IRA) bomb; or the bloodiest single atrocity of the conflict, the Omagh bomb of 15 August 1998 that took 29 civilian lives (both Protestant and Catholic), planted by a Republican splinter group known as the Real IRA. Given that the population of Northern Ireland numbered only around 1.4 million at the height of the conflict, no one, no matter how privileged, could wholly avoid its impacts. High levels of daily 
street violence and the indiscriminate bombing campaigns of the opposing Loyalist and Republican paramilitary forces ensured constant anxiety over personal safety and the safety of loved ones. While the Good Friday/Belfast Agreement of 1998 (signed 3 months before the Omagh bombing) began the process of halting violence, it is unsurprising that very high levels of post-traumatic stress disorder and elevated suicide rates remain a fact of daily life (Ferry et al. 2011; Tomlinson 2012). Furthermore, the violence has not entirely dissipated. Between 2002 and June 2019, 93 further murders have been attributed to the conflict.

Society in Northern Ireland continues to struggle to move beyond an essentialised divide between two dichotomous communities, Catholic, Nationalist, Republican (CDR) versus Protestant, Unionist, Loyalist (PUL). Historically, this division is rooted in the 16th- and 17th-century extension of English, later British political power through the mechanism of plantation, or planting loyal citizens (Canny 2001; Lyttleton and Rynne 2009; Horning 2013a, b, c). The most extensive of these efforts was the Ulster Plantation, launched in 1609 and intended to replace the Gaelic Irish with loyal Protestant settlers. The narratives that underpin division in today's Northern Ireland are popularly understood to be rooted in the Plantation period. As such, the Troubles have been widely interpreted by political analysts as a fundamentally ethnic conflict between the Catholic descendants of the Gaels and the Protestant descendants of the planters (McGarry and O'Leary 2000, but see McGratton 2010 for a contrasting viewpoint). In actuality, the Troubles resulted from a complex admixture of political, economic, and geographical factors rooted in 20th-century politics and economic inequalities. Since most who lived through it understand it to have been principally the result of (as yet unresolved) ethnic rivalry and antagonism, it is from that standpoint that any effort to effect positive change must begin.

While to most outsiders, the violence of the Troubles appears long consigned to history, the reality on the ground is very different. The recent (18 April 2019) murder of the journalist Lyra McKee by the paramilitary organisation known as the New IRA rightly made international headlines, particularly given its occurrence on the 21st anniversary of the Belfast/ Good Friday Agreement. But McKee's unlawful shooting should not be seen as a singular event. The previous month, the same organisation claimed responsibility for five letter bombs sent to addresses in England, and also were responsible for a car bomb that exploded in central Derry/ Londonderry in February 2019. Paramilitary activity is neither limited only to the City of Derry/Londonderry nor to the Republican cause. Loyalist as well as Republican paramilitaries take it upon themselves to serve as alternative arbitrators of justice in underprivileged, segregated communities. 
So-called punishment beatings doled out by paramilitaries have increased more than 60\% since 2012 (Beaudette 2013; McDonald 2018).

At the heart of this, dissident activity is a simple fact: the incomplete peace emerging from the Agreement is founded upon parity of esteem rather than working towards a society with a shared sense of identity. The current peace process is built upon a consociational model codified in the Good Friday/Belfast Agreement which strives to maintain a balance of power between the two communities, which are now roughly equivalent in size (Coakley 2009). This position of compromise and mutual respect has stemmed most, but not all, violence. However, it also institutionalises and reinforces division, in effect undermining efforts to build a truly shared future. In practice, this has meant that the divide has actually deepened, hardened, and become institutionalised. That legacies of the conflict itself have not been adequately addressed is starkly revealed by the sobering reality that the number of suicides in Northern Ireland since the Agreement has outstripped the number of deaths during the Troubles (Tomlinson 2012). Clinical evidence suggests that Troubles-related trauma, if unacknowledged and untreated, can be passed down to the next generation. Even more to the point is the reality acknowledged by McKee (2016) herself, as a member of the post-Agreement generation, in an article for The Atlantic: "We were the Good Friday Agreement generation, spared from the horrors of war. But still, the aftereffects of those horrors seemed to follow us". McKee recounted her own experiences of losing friends and family to suicide: "if I count their names on my fingers, I run out of digits".

The political failure to establish a widely acceptable means of addressing Troubles-related violence, crime, and alleged collusion between security forces and paramilitaries exacerbates the psychological trauma. Following the consociational model, leadership in the Northern Irish Assembly is held jointly under the Office of the First Minister and Deputy First Minister (OFMDFM). In practice, this has resulted in increasing support for the hardline parties on either side of the community divide: Republican Sinn Féin and the ultra-conservative Democratic Unionist Party (DUP). Their inability to govern together resulted in the collapse of the Assembly in January 2017, leaving the whole of the province devoid of any credible crosscommunity political body. The incomplete nature of the peace process, in the estimation of White (2013: 227), lies in the inability of the Belfast (Good Friday) Agreement "to transform the relationship between the two communities. It did not resolve fully the issues under dispute, as each side continues to interpret the conflict through its own lens (ie. history) and remains distrustful of its former enemies". Such mutual distrust is exemplified by collapse of the Assembly.

All of this is, of course, rendered even more challenging by the ongoing uncertainties of Brexit. At time of writing (June 2019), the deadlines for 
negotiating terms of the withdrawal of the United Kingdom from the European Union have come and gone without resolution. The sticking point in this negotiation is the fundamental incompatibility of Brexit efforts with the provisions of the Belfast/Good Friday Agreement which underpins the uneasy peace in Northern Ireland, and the integral role of the Republic of Ireland as well as the United Kingdom in upholding the provisions of that agreement. In the May 2016 Brexit referendum, the people of Northern Ireland voted overwhelmingly in favour to remain in the European Union. Unfortunately, this expression of a long-term trajectory for the future carries little weight in Westminster, especially given that only one of the two main Northern Irish parties, the Democratic Unionist Party (DUP), takes its seat in the Westminster Parliament. Republican Sinn Féin has always eschewed engagement in the UK governance at national level. The DUP, however, is in favour of a hard Brexit, in clear denial of the wishes of the majority of Northern Irish voters. It is the DUP voice that is heard in Parliament, and it is their support that props up the UK's current conservative government. The only small consolation for the Northern Irish population in this whole mess is that the whole of the UK has been made aware not just of the very existence of the province (with its European land border) but of its unique positionality.

Greater awareness of the challenges faced by Northern Ireland, while welcome, does not ameliorate the many unresolved legacies of the Troubles. The degree of collusion between Loyalist paramilitaries and the Royal Ulster Constabulary (RUC) - police force-remains is not fully understood or acknowledged. A case in point is the 1979 murder of the Catholic solicitor Pat Finucane by a Loyalist paramilitary group, the Ulster Defence Association, described by one analyst as the result of "collaboration between state security forces and Loyalist paramilitaries" (Rolston 2005: 181). Another example, the 1994 Loughinisland massacre in which six people were killed in a rural pub while watching the football World Cup, which was the subject of a June 2016 report by the Police Ombudsman which for the first time acknowledged the likelihood of active collusion on the part of the RUC. As explained by one commentator (McGovern 2017: 47), RUC collusion should be "understood in an active sense ('to conspire, connive or collaborate')". Illustrating the reluctance to pursue RUC culpability, however, was the remarkable decision by the PSNI in 2018 to instead arrest two journalists who contributed to a documentary exposing RUC collusion in the Loughinisland killings (Carroll 2018).

Similarly, numerous unresolved killings and disappearances from the Troubles relate to punishments meted out by the Republican paramilitaries against members of the Catholic community accused of being "collaborators" - those who reported on terrorist activities. Seventeen individuals, known as "the Disappeared", represent such victims of Republican 
paramilitary targeting (Peake and Lynch 2016; https://thedisappearedni.co.u $\mathrm{k} /$ ). The Independent Commission for the Location of Victims Remains (ICLVR) oversees work to locate and recover the Disappeared, employing a pragmatic approach whereby they safeguard any information they receive and keep all findings confidential bar the actual recovery and return of human remains to their families. The ICLVR-funded work by my colleagues at Queen's University Belfast employs forensic geology and archaeological survey to help locate and recover these individuals. In 2015, the bodies of Seamus Wright and Kevin McKhee were unearthed in a County Meath bog. Both men were IRA members who disappeared from West Belfast in 1972 after being accused of working undercover for the British. In 2017, the remains of Seamus Ruddy, murdered by the Republican paramilitary group the Irish National Liberation Army (INLA), were recovered in France. Three of the Disappeared still remain missing. Amidst the coverage of the death of Sinn Féin leader and prominent peace broker Martin McGuinness in 2017 were reminders of his role as IRA Commander in 1990 when accused "collaborator" Patsy Gillespie was used as a human bomb to destroy the Army checkpoint at Coshquin on the Derry-Donegal border, killing five soldiers and Gillespie himself.

\section{Archaeology and the Troubles}

Beyond the search for the Disappeared, what does any of this have to do with archaeology, and with "collaborative" archaeological practice? Monuments from the contested plantation period of the early 17th century are common in today's landscape, from the plantation towns themselves to fortified castles built by incoming planters, with their meanings and associations renegotiated and reconsidered by each generation. Many are clearly territorialized in terms of contemporary division whether it be through neglect, vandalism, or conversely, rehabilitation and interpretation depending upon the interests and identity of local communities and/or heritage bodies (Horning et al. 2015). Some sites are celebrated for their plantation associations, while others are ignored or even vandalised, depending upon the affiliation and identity of the local community.

Some plantation histories seem to have been wilfully forgotten. Three sites associated with a powerful early 17th-century Gaelic lord, Donal Ballagh O'Cahan, illustrate this process. The first is Dungiven priory and bawn (Fig. 1), site of an early medieval ecclesiastical house, medieval church, late medieval Gaelic tower house, and 17th-century plantation castle. Until archaeological work took place in the 1980s (Brannon and Blades 1980) uncovering the foundations of a manor house built by the English servitor Sir Edward Doddington in the first decades of the 17th century 


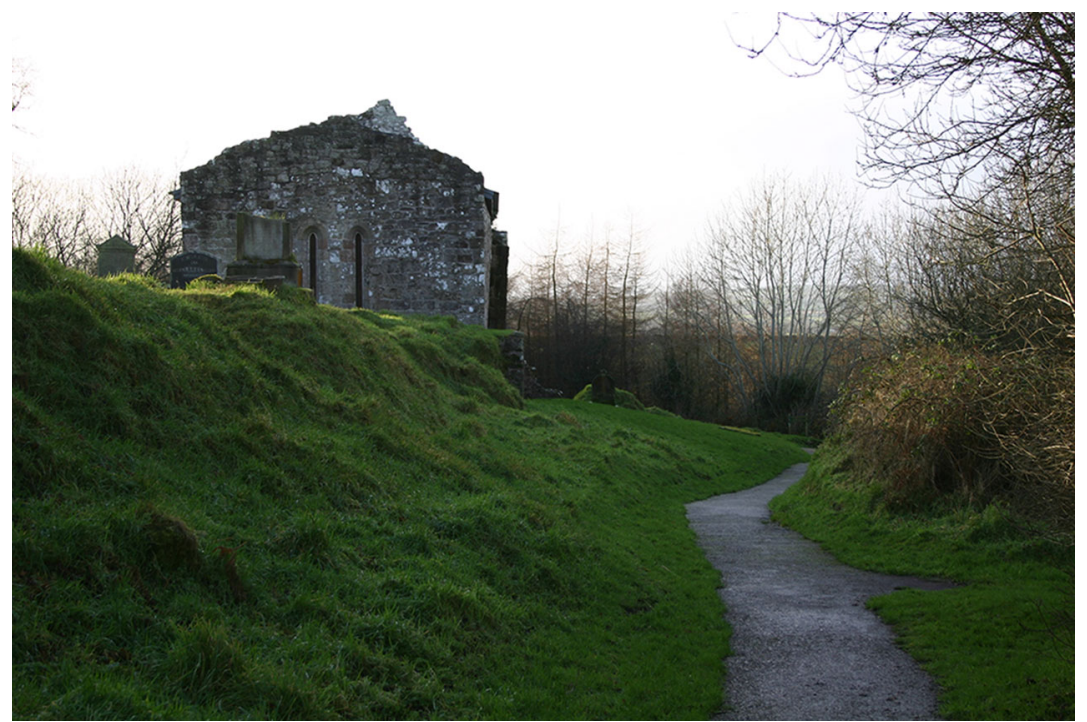

Figure 1. Dungiven priory and bawn. Photograph by Audrey Horning

following the confiscation of O'Cahan lands by the English, the very existence of any planter activity at this site was not part of local understanding in the majority Catholic village of Dungiven. Similarly, the site of another O'Cahan castle now lies within a country park near Limavady. Like Dungiven, this Roe Valley castle had been confiscated and turned over to another English servitor, Doddington's brother-in-law Sir Thomas Phillips. Phillips re-edified the O'Cahan castle and built an adjacent manor house as well as a fishery, brewhouse, and extensive formal gardens. Until 2009 (when I conducted excavations and contributed to an update of the park's interpretation), the only sign that greeted visitors at the site simply stated "O'Cahan's castle" (Fig. 2). Notwithstanding that the aim of my excavation was to address the multiple periods and associations of the site, a local newspaper report on the project intentionally employed the headline "O'Cahan's Secrets Revealed" (Londonderry Sentinel 23 April 2009) to attract readers.

By contrast, the majority Protestant town of Coleraine has invested time, effort, and funding to explore and interpret its history as one of the two walled towns of the Londonderry Plantation (launched in 1609). While Coleraine's plantation history is highly significant and materially visible in the townscape, Coleraine was also the site of a medieval church, and castle that in the 16th century was held by the O'Cahan lordship. Having taken a wide range of groups around Coleraine on archaeological walking tours, I 


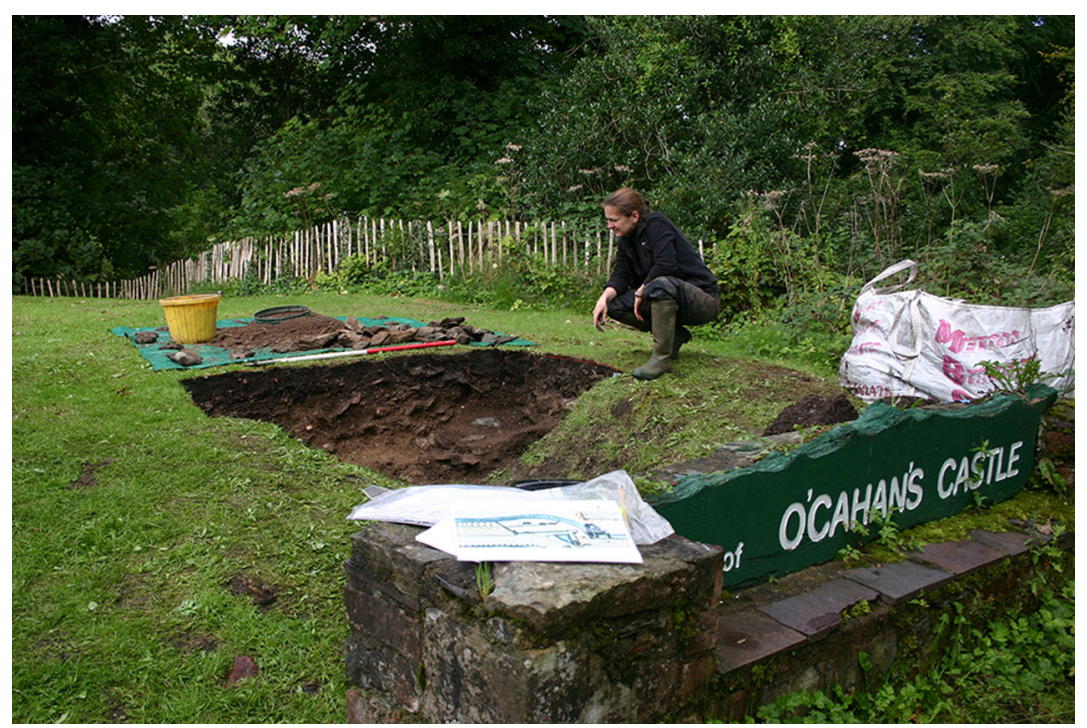

Figure 2. O'Cahan castle site. Photograph by Nick Brannon

have found people (including lifelong residents of Coleraine) to be astonished that there was anything of any note on the site before the plantation. Signs mark the location of major plantation features, but not the probable location of the medieval castle.

Divisive as they may seem on the surface, plantation period sites actually contain within them evidence for a more complicated past, revealing the intertwined nature of the Gaelic Irish world with that of the incoming planters. Plantation rhetoric emphasised the replacement of a "medieval" Gaelic world with that of a "modern" colonising force, yet archaeology underscores the failure of the plantation to attract settlers, the reliance of the few incomers on the local population for labour, food, and knowledge, and, crucially, the active involvement of the Gaelic elite in the practices and politics of plantation as well as the emergent capitalism of the early modern world (see for example Breen 2012a, b; Donnelly 2005, 2007; Horning 2013b). As such, the tangibility of archaeological evidence from the plantation period can provide a refutation of long-held sectarian narratives in ways much more viscerally powerful than words on a page. Consider Dungiven again. Inside the extent, medieval priory is an O'Cahan effigy tomb (Fig. 3). Such figural sculpture was elsewhere the target of Protestant reformers, yet the English Protestant planter Edward Doddington and his wife Anne seem to have consciously decided to preserve the 


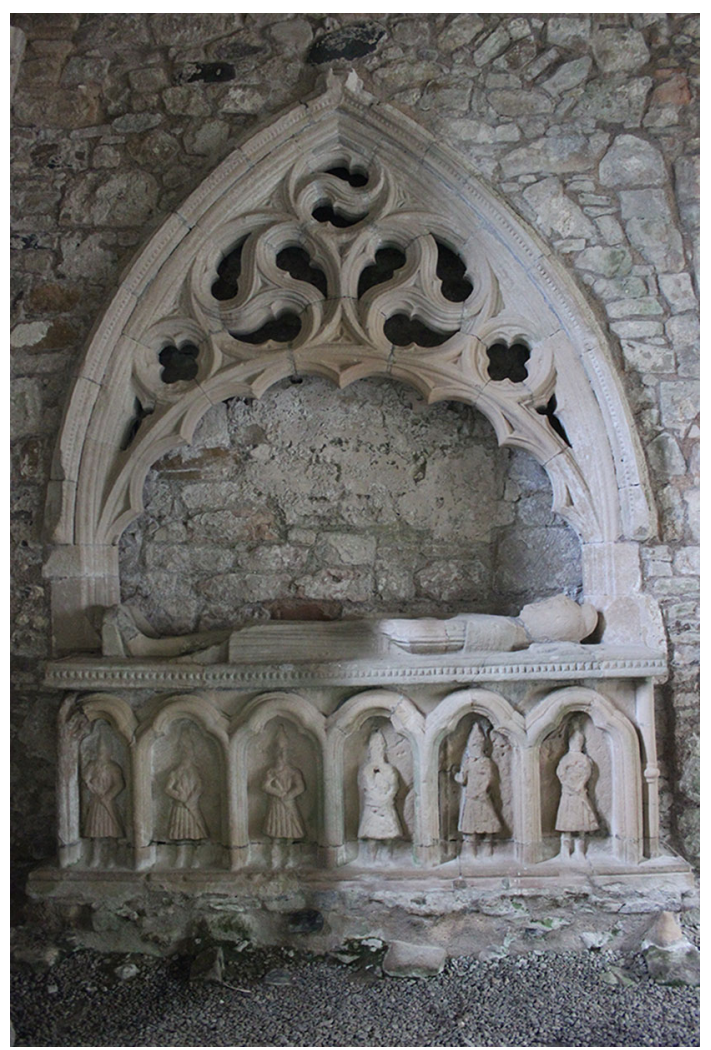

Figure 3. O'Cahan effigy tomb at Dungiven. Photograph by Audrey Horning

sculpture while converting the church into a house for Protestant worship. Taking community groups inside the ordinarily locked chancel to encounter this surprising survival of the Gaelic world invariably precipitates reflections over the possible motivations of the Doddingtons in their decision to preserve the tomb. What role was played by their relationship with their Irish Catholic tenants, or their relationship with the vestiges of the Gaelic elite? This example forces recognition that plantation was not an absolute process, but rather an incompletely executed paper plan. What mattered more on the ground was negotiating the needs and realities of the day.

Similarly, while Sir Thomas Phillips of Limavady vocally advocated the complete removal of all Irish from Londonderry plantation lands, he himself not only capitalised upon the confiscated O'Cahan buildings at Limavady, but he retained the O'Cahan tenants and adapted to their cattle economy (Horning 2018). A mix of Irish and English ceramics from the 
site hints at the material nature of cultural entanglements at Limavady. Returning to Coleraine, the dependence of incoming planters on the largely Catholic population remains overtly recognisable in the juxtaposition of the largely Protestant Coleraine town on the east side of the River Bann, overlooked by the historically Catholic settlement of Killowen, on traditional O'Cahan lands, on the other side of the Bann.

In short, the archaeological evidence of the plantation period challenges the fragile basis of the peace process by revealing a far messier, entangled past. As noted above, the use of a consociational model means that stability rests upon difference and maintaining parity and balance between the two communities, both of whom self-identify as the marginalized "other". Geographical segregation in the present is read into the past, with sites being seen as either Protestant or Catholic, but seldom, if ever, both. Any successful effort at advancing peace and transforming conflict rests upon finding spaces for discourse that recognizes the significant ways in which the histories of the two communities not only overlap but are thoroughly entangled.

It is this complexity that has been routinely overlooked by external critics of community-engaged archaeology, who see much engaged, multivocal practice as a sop to liberal academia that does little good for actual communities. To highlight one such recent critique, Alfredo González-Ruibal (2019: 51) describes multivocality in unflattering terms as "the excuse to embrace forms of soft politics that eschew structural inequality and conflict". Dismissing efforts to engage both Palestinians and Israeli Jews in heritage explorations as "a joke", he continues on to lambast our efforts in Northern Ireland (described further below) as merely "downplaying the existence of conflict in the past". While González-Ruibal is correct in highlighting the need to pay attention to structural inequalities particularly in a setting such as the West Bank, economic inequality in Northern Ireland is currently shared across the community divide, but masked by sectarianism. Critically examining the origins of sectarianism is fundamental to dismantling its impacts, in order to address economic inequalities. Furthermore, conflict is never downplayed in terms of addressing the past and acknowledging the present in the programmes that have been developed via a partnership between peace facilitators, academic archaeologists, and local authority heritage practitioners. Instead, considerations of conflict are overt and at the heart of the honest conversations that emerge from genuinely open engagement. One cannot avoid conversations about conflict in Coleraine, for example, given that some of the best examples of early 17thcentury archaeological features in the town were unintentionally revealed through the mechanism of the IRA bomb in November 1992 that gutted the town's historic core. 


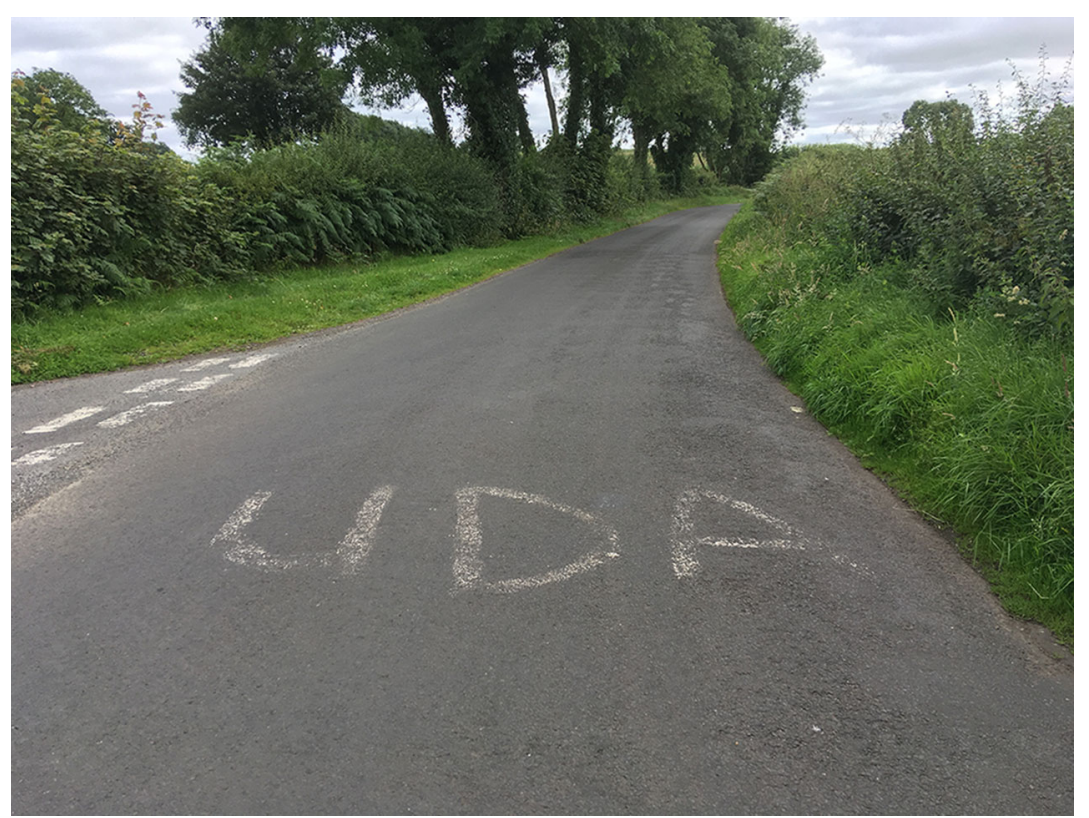

Figure 4. Ulster Defence Association paramilitary territorial marker. Photograph by Audrey Horning

The realities of the Troubles and their long legacy means that people from Northern Ireland have grown up attuned to the need to read their surroundings, to know a space is "theirs" or "the others". The notion of engaging the material world in considering identity is thus very familiar in a land where difference has always been materially marked. Murals, painted kerbstones, the use of some colours and not others, flags, and the theatricality of parading are traditional overt devices employed in marking territoriality. Some markers, such the faint lettering for the Ulster Defence Association painted on my own rural lane (Fig. 4), are more subtle but no less deliberate in intent and effect. In terms of cross-community projects, then, no one has to be introduced to the concept that archaeological objects are capable of holding multiple meanings. In the present, the labelling of places, on maps and road signs with names can be especially contentious, as demonstrated by the contortions of the placename Derry/ Londonderry (Fig. 5).

Plantation sites can not only serve as spaces for contemporary discourse and a re-imagining of the past in ways that challenge popular narratives, but also challenge accepted academic histories. And some of those histories themselves rely upon the provocative language of collaboration and collusion. By way of example, the historian Vincent Carey (1994), in discussing 


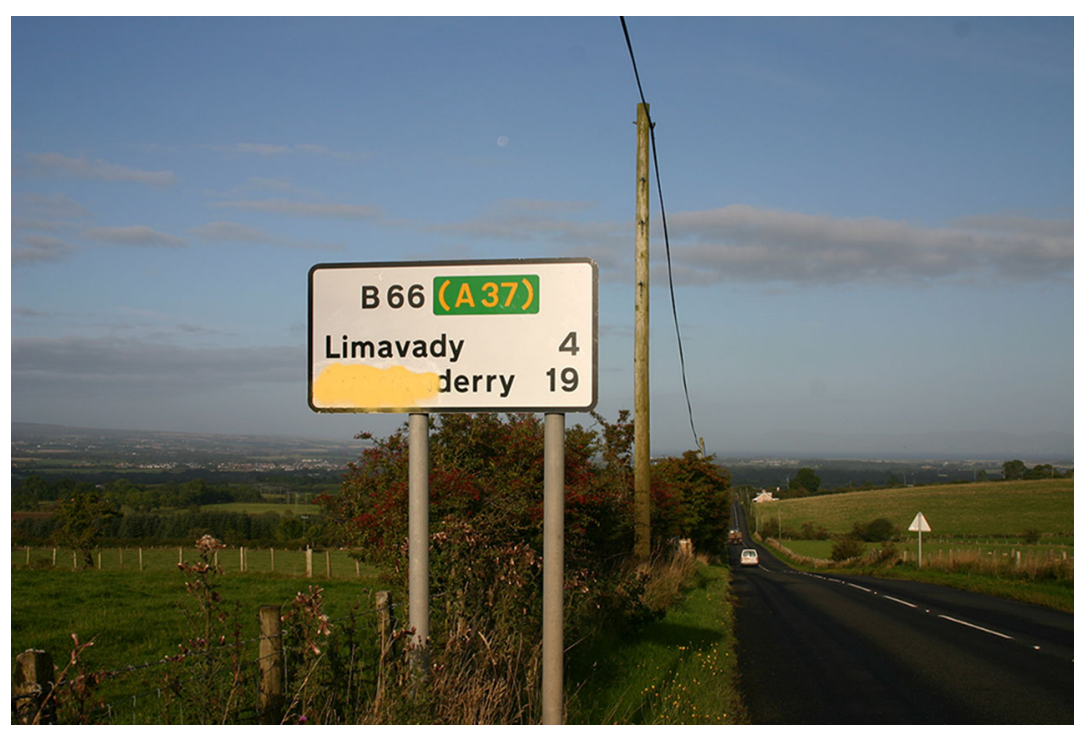

Figure 5. Contesting placenames: Derry/Londonderry. Photograph by Audrey Horning

the positionality of the (Old English and Catholic) eleventh earl of Kildare in the 16th century, describes him as a "Tudor collaborator" defining collaboration thus: "collaboration usually implies betrayal, or deviation from some sanctified course". Carey deliberately employed this terminology in a manner that would resonate in the present. We are not meant to like the eleventh earl of Kildare because he betrayed the cause of Catholic Ireland. But that particular cause is only found when reading backwards. There was no sense of a unified Ireland in the 16th century (it was instead characterised by independent and competitive lordships like that of the O'Cahan), and Kildare was only acting like any other strategic elite faced with the potential erosion of his power. That is actually a story that people in the present can readily understand, particularly given the often puerile nature of politics in Northern Ireland. And it is a story that hardly underplays conflict in the past.

\section{Integrating Archaeology and Conflict Transformation}

The "peace dividend" that has seen increased investment coming to Northern Ireland in aid of the peace process has provided the opportunity to more overtly integrate archaeology and heritage practice into conflict transformation, aided by European Union peace and reconciliation funding (its 
continuance now threatened by Brexit) and a growing willingness on the part of some (but by no means all) local authorities to engage in "riskier" heritage-related programmes. The most significant programmes that I have been involved with have been conducted via a partnership between university archaeologists, museum professionals, and the trained facilitators of Northern Ireland's oldest peace charity, the Corrymeela Community (a shared governance body formed in 1965), with a wide range of community partners (Horning and Breen 2018; Horning 2019). Fundamental to our work are a series of principles that prioritise respect for participants and their perspectives (Pettis 2015), in accordance with the guiding philosophy of an archaeology of listening (Schmidt and Kehoe 2019). Endeavours include our recent (2014-2016) Contact, Culture and Conflict around the Causeway project, current (2019) National Heritage Lottery Funded project Our Place, our Pasts, and our Perspectives, and a 2018 Heritage as Reconciliation international workshop. Our projects emphasise peacebuilding, community development, and sustainability and range from incorporating local community groups and schoolchildren in field projects focusing on plantation period sites, to more risky (and rewarding) initiatives including intensive weekend residential programmes with groups and individuals that include victims and survivors, former combatants and paramilitaries, as well as the economically marginalised (Horning and Breen 2018; Horning 2019). These weekends focus on immersive engagement with sites and artefacts.

Given the precarity and fragility of life in Northern Ireland, it has been crucial that we work alongside trained facilitators to ensure that archaeological agendas-our desire to share what we have learned and think-do not cause harm (Horning and Breen 2018; Horning et al. 2015; Horning 2019). The deconstruction of long-held narratives can on occasion render community partners anxious and sometimes angry. One programme participant expressed a common sentiment, seeing the experience as: “...unsettling as there's a lot of things need clarified. It will help me look at things differently question them more and look for the real meaning" (quoted in Pettis 2016). It is not easy for people to look into a mirror, and question the very foundations of their identities as well as the increasingly institutionalised divisions of the present. But the physicality of the past serves as a very useful mediating device as well as being harder to deny than yet another speech by a politician or impassioned lecture by an out of touch academic. As archaeologists, we know that the evidence, and indeed the past itself, is ambiguous and capable of multiple readings. This recognition is not always shared outside of the profession, but when it is, it can be emancipatory.

The willingness of people to test their own understandings through engagement with archaeological evidence, not to mention with archaeolo- 
gists, is dependent upon the recognition by all participants that we are working together in a safe space created through consensus and co-production (Breen et al. 2015; Horning et al. 2015; Horning and Breen 2018; Horning 2019, 2013c). Most importantly, and contra González-Ruibal's assumptions about our work, our programme conversations inevitably revolve around conflict and violence because that is the context within which we live and work in the present, and which informs contemporary understandings of the past. It takes no stretch of the imagination for someone who endured the Troubles, whether as a perpetrator, victim, or witness (or indeed, all three), to acknowledge the proximity of daily human relations that can concomitantly provoke or prevent violent actions, be it in a 17th-century alehouse with a mixed clientele, or a Border pub in the 1980 s, or an interface in North Belfast in the 2000s. Violence is not only central to the understandings of our partners who lived through the Troubles, but is also central to the understandings of the post-Agreement generation like the murdered journalist Lyra McKee discussed above, many of whom struggle to understand and deal with intergenerational trauma. Young people facing economic hardships, especially so-called "NEETS" (not in education, employment or training) are susceptible to being lured into membership of paramilitary organisations, where they find purpose and structure and excitement (Kingsley 2019; McGlinchey 2019). The Creggan area of Derry/Londonderry, where McKee was shot by an as yet unidentified paramilitary in April 2019, has a child poverty rate of nearly $50 \%$ in a city at the bottom of the list in terms of the United Kingdom's urban economies. That dissident paramilitary numbers are thankfully still low, and the prospect of any return to wide-scale violence with broad community support seems minimal, does not diminish the psychological impact of sporadic paramilitary violence on individuals already scarred by the past. Nor does it erase the fundamental structural inequities that have left many with limited options in a country with no functioning government in the midst of the ongoing anxieties of the Brexit process.

It is within this wider context of uncertainty that we work as members of Northern Irish society trying to build a better future through the tools that we individually possess. From the Corrymeela perspective as peace facilitators, the most significant element of our heritage projects is the actual process; creating safe space where individuals of different backgrounds can be supported and empowered to come together and engage respectfully. One additional outcome that I, as an archaeologist, seek in our projects is a pretty simple acknowledgement that people in the past could not predict the future. In other words, the Irish and English and Scots who were thrown together during Plantation cannot be held directly responsible for the events of the 20th-century Troubles. They, like our participants in the present, made both good and bad decisions that may have 
had lasting consequences, but those consequences could never have been known nor predicted at the time.

I also recognise that the mobilisation of the plantation past for the benefit of the future involves choices. The need to balance issues of evidence, ethics, and respect for individual and community narratives is the subject of constant negotiation. At the same time, it is core to the development of an empirically informed, ethically engaged archaeological practice. Perspectives gained from cross-community partners have not only improved this practice, they have also opened up new interpretative possibilities, echoing Alison Wylie's (2015) endorsement of collaborative practice as the locus for "some of the most creative archaeological learning". Given my reservations about the term collaboration, I will rephrase this process as "co-production" while recognising that uncritical use of "co-production" implies an equality and unanimity of intent which is seldom present. Agendas are never wholly shared or in concert, but it is the spaces of overlap that can prove most productive.

Prioritising peacebuilding and inclusivity necessitates a lessening of control, and a conscious (not tacit) acknowledgement that one is making a choice in how to interpret and approach the past. Doing so without compromising or abandoning our concomitant ethical responsibilities to the living and the dead and the actualities of their experiences is extraordinarily difficult. Additionally, I have had to be honest with myself about my own positionality both personally and professionally. Personally, I have my own family-inherited baggage about the Troubles, and my attitudes have of course been influenced by daily lived experience in the province. I know which party I have cast my own vote for at the ballot box, and also to which community I am de facto perceived to belong. I take perverse pleasure in the fact that I have always declined to provide a community identity to Queen's University Belfast, forcing the human resources department (following equal opportunities legislation) to identify me as either [perceived] Catholic or [perceived] Protestant based on factors such as my postcode and/or the fact that I hold a Republic of Ireland passport. Professionally, my theoretical stance on understanding identity as fluid and dynamic could easily get in the way of appreciating and respecting the strength of others' personal narratives, which can be more rooted in fixed notions of essential identities. Strategic essentialism, familiar in many postcolonial settings, plays a role in reifying community solidarity. But rather than being positively empowering, in the Northern Ireland context, strategic essentialism can negatively confound efforts to transcend divisions.

Recognising that the Troubles are widely understood to be about ethnic rivalry rooted in such essentialised identities is the standpoint from which any effort to effect positive change must begin. This is not the "soft politics" derided by González-Ruibal (2019), who castigates anyone who does 
not choose a side and seems to believe that the rights and wrongs of the Northern Irish conflict are readily discernible. The side I have chosen is that of the future, not of the past. Moving forward requires recognising multiple viewpoints, identifying bridging mechanisms, and building peace slowly and deliberately. We need to shift our focus from choosing sides, to instead look to the future and to the next generation, and to no longer frame relations only by looking to an often wilfully misunderstood past. The value of an underpinning in pragmatism is that these choices, while difficult, become acceptable and even desirable when the focus is on social justice and a peaceful future that is cognizant of the complexities of and possibilities from the past.

\section{Conclusion}

My understanding of the term collaboration is undeniably coloured by its often pejorative meaning in the context of Northern Ireland. As such, I am under no illusion that practitioners will suddenly abandon its use in acknowledgement of my concerns. However, I do hope that the Northern Ireland situation can prove instructive in other places and spaces where we seek to contribute positively to society and to the future. Every conflict or post-conflict situation is different, and language is contextual. But peacebuilding anywhere must at least start from a standpoint of acknowledging multiple perspectives. Make no mistake, I have my own strong personal views about politics in Northern Ireland and what I hope for the future. But I will not be a collaborator-a partisan-when such an action would negate the possibility of that peaceful future. The archaeology of the plantation period undermines the ethnic conflict model of the Troubles by demonstrating far more ambiguous cross-cultural engagements in the past. As such, it also challenges contemporary separation and the current structure of the peace process. In doing so, it neither downplays nor dismisses the centrality of conflict in those engagements and in the past. At the same time, the ambiguous character of the past, and the lack of direct correlation to assumed narratives in the present, provides a space for reconsidering the future. For lasting peace, some sense of a shared history and shared future has to take root in a society where there is no majority. Its seeds exist in the evidence of the past, and in people's willingness to engage with one another to rethink sectarian narratives. If we succeed in our efforts to recast historical understandings, we will eliminate the need for parity of esteem between two separate communities because the boundaries between the two will be fundamentally eroded. And if and when that happens, collaboration might cease to be such a dirty word. 


\section{Acknowledgements}

Institutional support for the work discussed in this article was provided by Queen's University Belfast and the College of William and Mary. The Heritage Lottery Fund (now National Lottery Heritage Fund) provided financial support for the projects discussed above. I would like to thank my project partners Colin Breen, Robert Heslip, Helen Perry, Sean Pettis, and Gemma Reid, as well as the Corrymeela Community itself. I am particularly grateful to all of our community partners and programme participants for the many lessons they have brought to the table that continue to shape practice. I have also benefited from conversations about the issues in this article with Nick Brannon, Stephen Mrozowski, George Nicholas, Jane Schmidt, Peter Schmidt, and Rachel Tracey. I am very grateful to Bonnie Clark and Ian Kuijt for their valuable and incisive suggestions on an earlier draft.

Open Access This article is distributed under the terms of the Creative Commons Attribution 4.0 International License (http://creativecommons.or g/licenses/by/4.0/), which permits unrestricted use, distribution, and reproduction in any medium, provided you give appropriate credit to the original author(s) and the source, provide a link to the Creative Commons license, and indicate if changes were made.

\section{References}

Atalay, S.

(2012). Community-based archaeology: Research with, by and for indigenous and local communities. California: University of California Press.

Beaudette, D.

(2013). Beyond coercion: The politics of punishment attacks and policing. $\mathrm{PhD}$ thesis, Emory University.

Brannon, N. F., \& Blades, B.

(1980). Dungiven Bawn re-edified. Ulster Journal of Archaeology, 43, 91-96.

Breen, C.

(2012a). Dunluce castle, history and archaeology. Dublin: Four Courts Press.

(2012b). Randal MacDonnell and early seventeenth-century settlement in Northeast Ulster, 1603-30. In M. O. Siochru \& E. O. Ciardha (Eds.), The Plantation of Ulster: Ideology and Practice (pp. 143-157). Manchester: Manchester University Press. 
Breen, C., Reid, G., \& Hope, M.

(2015). Heritage, identity and community engagement at Dunluce Castle, Northern Ireland. International Journal of Heritage Studies, 20(8), 919-937.

Canny, N.

(2001). Making Ireland British: 1580-1640. Oxford: Oxford University Press.

Carey, V. P.

(1994). Collaborator and survivor? Gerald the eleventh earl of Kildare and Tudor rule in Ireland. History Ireland, 2(2), 13-17.

Carroll, R.

(2018, August 31). Loughinisland killings: Journalists arrested over alleged document theft. The Guardian. https://www.theguardian.com/uknews/2018/au g/31/loughinisland-killings-journalists-arrested-over-stolen-documents. Accessed 31 August 2018.

Coakley, J.

(2009). Implementing consociation in Northern Ireland. In I. R. Taylor (Ed.), Consociational theory: McGarry and O'Leary and the Northern Ireland Conflict (pp. 122-145). London: Routledge.

Colwell-Chanthaphonh, C., \& Ferguson, T. J. (Eds.).

(2008). Collaboration in archaeological practice: Engaging descendant communities. Lanham: AltaMira Press.

Donnelly, C.

(2005). The I.H.S. monogram as a symbol of Catholic resistance in 17th-century Ireland. International Journal of Historical Archaeology, 9(1), 37-42.

(2007). The archaeology of the ulster plantation. In A. Horning, R. Ó. Baoill, C. Donnelly, \& P. Logue (Eds.), The archaeology of post-medieval Ireland, 1550-1850 (pp. 37-50). Wordwell: Dublin.

Ferry, F., Bolton, D., Bunting, B., O’Neill, S., Murphy, S. \& Devine, B.

(2011). The economic impact of post traumatic stress disorder in Northern Ireland. www.nictt.org. Accessed 12 February 2017.

González-Ruibal, A.

(2018). Ethics of archaeology. Annual Review of Anthropology, 47, 345-360.

(2019). An archaeology of the contemporary era. London and New York: Routledge.

Horning, A.

(2013a). Exerting influence? Responsibility and the public role of archaeology in divided societies. Archaeological Dialogues, 20(1), 19-29.

(2013b). Ireland in the Virginian Sea: Colonialism in the British Atlantic. Chapel Hill: University of North Carolina Press. 
(2013c). Politics, publics, and professional pragmatics: Re-envisioning archaeological practice in Northern Ireland. In C. Dalglish (Ed.), Engaging the recent past Woodbridge (pp. 95-110). Boydell and Brewer: Suffolk.

(2019). Listening, hearing, choosing: The challenge of engaging archaeology in conflict transformation. In P. Schmidt \& A. Kehoe (Eds.), Archaeologies of listening (pp. 202-223). Gainesville: University of Florida Press.

Horning, A., \& Breen, C.

(2018). In the aftermath of violence: heritage and conflict transformation in Northern Ireland. In P. Newson \& R. Young (Eds.), Post-Conflict archaeology and cultural heritage: Rebuilding knowledge, memory and community from war-damaged material culture (pp. 177-194). London: Routledge.

Horning, A., Breen, C., \& Brannon, N.

(2015). From the past to the future: Integrating archaeology and conflict resolution in Northern Ireland. Conservation and Management of Archaeological Sites, 17(1), 5-21.

Kingsley, P.

(2019). Things stopped changing: Why conflict still flares in Northern Ireland, New York Times, 30 April 2019.

La Salle, M., \& Hutchings, R. M.

(2018). What could be more reasonable? Collaboration in colonial contexts. In A. M. Labrador \& N. A. Silberman (Eds.), The Oxford handbook of public heritage theory and practice. Oxford: Oxford University Press.

Lyttleton, J., \& Rynne, C. (Eds.).

(2009). Plantation Ireland. Dublin: Four Courts Press.

Martindale, A., \& Nicholas, G.

(2014). Archaeology as federated knowledge. Canadian Journal of Archaeology, $38,434-465$.

McDonald, $\mathrm{H}$.

(2018). Northern Ireland punishment attacks rise 60\% in four years. The Guardian, March 12. https://www.theguardian.com/uk-news/2018/mar/12/nor thern-ireland-punishment-attacks-rise-60-in-four-years. Accessed 1 May 2019.

McGarry, J., \& O’Leary, B.

(2000). Explaining Northern Ireland: Broken images. Oxford: Blackwell.

McGlinchey, M.

(2019). Unfinished business: The politics of 'dissident' Irish republicanism. Oxford: Oxford University Press. 
McGovern, M.

(2017). "See no evil": Collusion in Northern Ireland. Race and Class, 58(3), 4663.

McGratton, C.

(2010). Explaining Northern Ireland? The limitations of the ethnic conflict model. National Identities, 12(2), 181-197.

McKee, L.

(2016). Suicide among the ceasefire babies. The Atlantic, January 20.

Mrozowski, S. A.

(2011). Pragmatism and the relevancy of archaeology for contemporary society. In M. Rockman \& J. Flatman (Eds.), Archaeology in society: Its relevance in the modern world (pp. 239-256). New York: Springer.

Nicholas, G.

(2010). Being and becoming indigenous archaeologists. Walnut Creek: Left Coast Press.

Peake, S., \& Lynch, O.

(2016). Victims of Irish republican paramilitary violence: The case of the disappeared. Terrorism and Violence, 28(3), 452-472.

Pettis, S.

(2015). Contact, Culture and Conflict around the Causeway. Corrymeela Magazine, 15(2), 12-13.

(2016). Evaluation: Contact, culture and conflict around the causeway. Report submitted to the Heritage Lottery Fund, Belfast.

Preucel, R. W., \& Bauer, A.

(2001). Archaeological pragmatics. Norwegian Archaeological Review, 34, 85-96.

Preucel, R. W., \& Mrozowski, S. (Eds.).

(2010). Contemporary archaeology in theory: The new pragmatism. Malden, MA: Blackwell Press.

Rolston, B.

(2005). An effective mask for terror: Democracy, death squads and Northern Ireland. Crime, Law and Social Change, 44, 181-203.

Silliman, S.

(2008). Collaborating at the Trowel's Edge: Teaching and learning in indigenous archaeology. Tucson: University of Arizona Press.

Sutton, M.

(2001). An index of deaths from the conflict in Ireland. http://cain.ulst.ac.uk/sut ton/. Accessed 1 March 2018.

Tomlinson, $\mathrm{M}$.

(2012). War, peace, and suicide: The case of Northern Ireland. International Sociology, 27(4), 464-482. 
White, T. J.

(2013). Lessons from the Northern Ireland peace process. University of Wisconsin Press.

Wylie, A.

(2015). A plurality of pluralisms: Collaborative practice in archaeology. In J. Y. Tsou, A. Richardson, \& F. Padovani (Eds.), Objectivity in science (pp. 189-210). New York: Springer.

Publisher's Note Springer Nature remains neutral with regard to jurisdictional claims in published maps and institutional affiliations. 